\title{
MODUL PENENTUAN HUKUM MAKANAN \\ UBAH SUAI GENETIK (GMF) DAN \\ KEPENTINGANNYA KEPADA UMAT ISLAM*
}

\section{Module of Islamic Law Regarding Genetically Modified Foods (GMF) and It's Importance to Muslims}

\author{
Sharif Mohd Tahir ** \\ Mohd Izhar Ariff Mohd Kashim ***
}

\begin{abstract}
This article discusses the importance of building the module to determine the status of genetically modified food (GMF) and its importance to Muslims based on Maqasid Shariah. GMF is a modern food products produced through biotechnology engineering with methods to manipulate the deoxyribonucleic acid (DNA) of plant, animal and so on. As a result, the process produces food which are more nutritious and contain more nutrients than natural food products. GMF are also able to be produced in large quantities and incur little cost compared to natural food through genetic modification process. There is still no any guidelines or module that can be used to determine the ruling status of the GMF products. The objective of this study is to produce guidelines
\end{abstract}

\footnotetext{
* Artikel ini merupakan modul bagi projek penyelidikan kod FRGS/2/2013/ SSI03/UKM/03/2 tajuk Pembinaan Modul Hukum Produk Bioteknologi Moden Bagi Hub Halal Jakim Menurut Kerangka Maqasid Shariyyah.

** Postgraduate Student at Department of Syariah, Faculty of Islamic Studies, National University of Malaysia, sharif.mtahir@gmail.com

*** Senior Lecturer at Department of Syariah, Faculty of Islamic Studies, National University of Malaysia, izhar@ukm.edu.my
} 
in module that should be used in determining the status of GMF that had been through biotechnology engineering process. Further, this study also seeks to clarify the importance of guidelines to determine the ruling status of GMF for Muslims. To make this study successful, data collection was conducted by using a qualitative design using library methods, descriptive, comparative, and content analysis of the sources in fiqh and science. Through the research conducted, GMF products can be eaten if they suit certain principles that have been outlined. Through these principles, the application of the ruling determines the products of GMF will be more organized. This study is significant to overcome the ambiguity of the ruling status of the GMF. It also aims to help the relevant authorities in determining the ruling of the products based on GMF products.

Keywords: Modern Biotechnology, Genetically Modified Foods (GMF), Islam, Halal, Maqāṣid Syarī'ah

\section{PENDAHULUAN}

Dewasa ini ramai pengusaha produk makanan yang mula menghasilkan makanan ubah suai genetik (GMF) kerana ia dikatakan lebih berkhasiat serta mampu dilaksanakan dengan melibatkan kos yang lebih rendah dan mampu mengeluarkan hasil dengan kuantiti yang lebih banyak. Namun, produk GMF belum mempunyai hukum yang jelas sama ada ia halal atau haram di sisi syarak. Sesuatu makanan yang mengandungi unsur baharu memerlukan kepada hukum yang baharu. Justeru, bagi meneyelesaikan permasalahan yang berlaku berhubung hukum makanan ubah suai genetik maka, makanan yang dihasilkan itu perlu melalui proses penilaian yang teliti oleh pihak berwajib seperti agensi-agensi kerajaan yang bertanggungjawab dalam hal ini. Proses penilaian dilakukan secara berperingkat merangkumi, penyediaan, pemprosesan, penyimpanan, pembungkusan, pengendalian dan pengangkutan. 


\section{Definisi Makanan}

Menurut istilah dalam Kamus Dewan, makanan didefinisikan sebagai apa sahaja yang boleh dimakan seperti nasi, roti dan lain-lain. ${ }^{1}$ Makanan dalam bahasa Arab disebut sebagai at 'imah, iaitu kata jamak kepada perkataan ța 'àm yang bermaksud segala yang dimakan. Manakala perkataan makan iaitu ța 'ām bermaksud merasai sesuatu sama ada pahit, manis, masam, masin dan sebagainya. Ibn al-Athīr pula lebih cenderung merujuk perkataan makanan kepada makanan asasi seperti gandum, tamar, sya 'ir dan sebagainya. Makanan klasik adalah makanan yang tidak melalui sebarang proses kejuruteraan bioteknologi berbeza dengan makanan GMF.

\section{Definisi Makanan Halal}

Halal berasal daripada kalimah arab yang bermaksud dibenarkan atau dibolehkan oleh hukum syarak. Dalam menentukan makanan itu adalah halal di sisi syarak maka sesuatu makanan itu bukanlah terdiri daripada atau mengandungi bahagian atau benda dari haiwan yang dilarang dalam Islam memakannya atau yang tidak disembelih mengikut syarak. ${ }^{2}$ Selain itu, makanan itu mestilah bebas dari memberi kemudaratan kepada kesihatan dan tidak membahayakan nyawa orang yang memakannya. ${ }^{3}$

Makanan tersebut juga mestilah bebas dari mengandungi sebarang unsur yang dihukum sebagai najis mengikut hukum syarak serta tidak diproses menggunakan alatan yang bersifat najis atau mengandungi najis mengikut hukum syarak.

\section{Definisi Makanan Ubah Suai Genetik (GMF)}

Makanan ubah suai genetik (GMF) adalah makanan yang telah melalui proses kejuruteraan genetik dengan mengubah struktur dan ciri-ciri gen secara langsung. Asid Deoksiribonukleik (DNA)

Kamus Dewan, ed. ke-4 (Kuala Lumpur: Dewan Bahasa dan Pustaka, 2002), 981.

2 Muhammad Ibn al-Jarīr al-Ṭabarī, Jāmi“ al-Bayān fì Ta'wīl alQur'ān (Bayrūt: Mu'assasat al-Risālah, 2000), 4:214.

3 Muḥammad Ibn Aḥmad al-Qurțubī, al-Jāmi ' li Aḥkām al-Qur'ān (Dimasyq: Dār al-Fikr, 1998), 2:363. 
dimanipulasi melalui proses penggabungan dan pengasingan antara DNA satu organisma dengan DNA satu organisma yang lain. Proses ini akan menghasilkan satu organisma yang baru yang tidak akan wujud secara semula jadi. Makanan ubah suai genetik merupakan makanan yang dihasilkan daripada organisma ubah suai genetik dengan mengubah gen tumbuhan atau haiwan untuk tujuan tertentu. Makanan ubah suai genetik lebih jimat dari sudut ekonomi, dan mempunyai daya tahan racun perosak, serangga, mempunyai jangka hayat yang lama, serta lebih berkhasiat berbanding tumbuhan atau haiwan yang asal. Teknik ubah suai genetik ini telah ada sejak zaman dahulu namun menggunakan teknik yang berbeza. Beberapa contoh teknik bioteknologi konvensional yang telah ada sekian lamanya adalah penggunaan mikro-organisma dalam proses pembuatan roti, wain atau menggunakan rennin untuk membuat. ${ }^{4}$

Sementara itu, bioteknologi moden atau lebih dikenali sebagai biologi molekul melibatkan teknik terkini yang canggih yang membolehkan saintis unuk mencapai sasaran yang sama tetapi dengan lebih cepat dan tepat. Walaupun terdapat pelbagai definisi bioteknologi moden tetapi kebanyakan peraturan di peringkat antarabangsa dan di negara maju bersetuju bahawa bioteknologi moden berbeza daripada teknik klasik seperti teknik pembiak baka dan mutagenesis. Bioteknologi moden melibatkan pengubahsuaian secara selektif dan sengaja DNA sesuatu organisma dengan campur tangan manusia sama ada melibatkan penyelitan, pengubahsuaian atau pengeluaran gen-gen tertentu menggunakan teknik biologi molekul atau DNA rekombinan. Dalam kes percampuran protoplasma atau sel, hanya teknik yang dapat mengatasi halangan pembiakan fisionlogi semula jadi diambil kira.

Salah satu teknik yang telah banyak digunakan ialah pengklonan yang merujuk kepada proses penggandaan DNA, sel atau organisma yang serupa secara genetik. Pengklonan haiwan merujuk kepada penggandaan haiwan yang serupa dari

4 Wan Jasimah Wan Mohammed Radzi, "Makanan Ubah Suaian Genetik: Perspektif Kesihatan dan Keselamatan Makanan", Kertas Kerja Seminar Muzakarah Pakar Makanan - Satu Perspektif Islam (Kuala Lumpur: Institut Kefahaman Islam Malaysia (IKIM), 2002). 
segi genetik melalui kaedah Pemindahan Nukleus Sel Somatik. ${ }^{5}$ Organisma hidup yang diubah suai secara genetik (GMO) adalah merupakan organisma yang genetiknya telah diubahsuai melalui kaedah bioteknologi moden. Ia berlaku melalui pembiakan atau rekombinan semula jadi atau kedua-duanya yang tidak berlaku secara semula jadi.

Mengikut Codex Committe on Food Labelling yang mewakili program bersama FAO dan WHO yang telah bersidang kali ke 39 di Quebec City, Quebec, Kanada pada 9-13 Mei 2011 menjelaskan bahawa makanan ubah suai genetik (GMF) adalah makanan dan ramuan makanan yang mengandungi GMO yang dihasilkan menerusi kaedah bioteknologi moden. Definisi GMF ini sebenarnya turut mempunyai persamaan dengan definisi yang dijelaskan oleh peraturan-peraturan Makanan Pindaan 2010.

Terdapat lima transgenik yang telah diluluskan di Malaysia sebelum undang-undang biokeselamatan diwujudkan dalam perlembagaan undang-undang Malaysia, iaitu kacang soya roundup ready, jagung MON 810, jangung MON 863 dan jagung NK 603. Ia digunakan sebagai makanan bagi ternakan dan pemprosesan protein membentuk ais yang dihasilkan daripada yis GM untuk digunakan dalam pembuatan aiskrim.

Kejuruteraan genetik merupakan teknologi untuk memanipulasi DNA atau gen. Proses tersebut digunakan untuk memperbaiki DNA ke arah yang lebih baik, iaitu menambah DNA asing ke dalam molekul DNA yang dimiliki oleh haiwan, tumbuhtumbuhan dan manusia. Tujuannya untuk mengubah maklumat genetik asal kepada genetik yang lebih baik agar ia mampu menghasilkan sejenis protein yang baru. Kemudian, protein ini akan menyebabkan organisma berkenaan mampu menonjolkan fenotip baru yang diinginkan. Kejuruteraan genetik ini juga boleh dijelaskan melalui dua aplikasi seperti berikut:

a. Teknik memanipulasikan asid nukleik secara in vitro yang melibatkan proses rekombinan DNA dan menyuntiknya ke dalam sel atau organel.

$5 \quad$ Bruce A., Gertz R., Oram C., Suk J., Tait J., Warkup C., \& Whitelaw B., Animal Cloning and Genetic Modification: A Prospective Study, Genesis Faraday (Scotland: Roslin BioCentre, 2005), 19. 
b. Teknik menggabungkan sel-sel yang tidak mungkin dapat berlaku melalui pembiakan fizikal secara semula jadi. ${ }^{6}$

Proses tersebut akan menghasilkan beberapa istilah penting sehingga melahirkan produk makanan, iaitu organisma terubah suai genetik GMO dan GMF. GMO dikenali sebagai organisma transgenik, manakala GMF merupakan produk makanan yang terhasil daripada GMO. ${ }^{7}$ Contohnya, terdapat sesetengah organisma transgenik yang diprogramkan supaya mengalirkan hasil secara pukal, khususnya dalam penghasilan enzim, antibiotik, nutrien, hormon dan pelbagai produk farmaseutikal seperti dadah dan vaksin. ${ }^{8}$

\section{Modul Penentuan Hukum Makanan Ubah Suai Genetik (GMF)}

Modul menurut Kamus Dewan Edisi Keempat, ${ }^{9}$ iaitu unit atau bahagian tersendiri yang lengkap dengan komponennya yang melaksanakan fungsi tertentu dan dapat dirangkaikan dengan unit-unit lain dalam sesuatu yang lebih besar. Pada masa kini, masih belum ada modul khusus yang membincangkan mengenai penentuan hukum makanan GMF secara teliti dan teratur. Justeru, perlu ada pihak yang memainkan peranan mengisi kelompangan yang ada untuk mașlaḥah umat Islam. Oleh itu, modul ini dihasilkan bertujuan untuk mengisi kelompangan tersebut dengan membincangkan prinsip-prinsip yang perlu diikut dalam penentuan hukum makanan GMF agar selari dengan hukum syarak bagi membolehkan produk GMF dimakan oleh umat Islam tanpa ragu-ragu.

Makanan ubah suai genetik boleh dimakan sekiranya mengikut beberapa garis panduan yang dikira amat wajar diikuti bagi

6 World Health Organization (WHO), Modern Food Biotechnology, Human Health and Development: An Evidence-Based Study (Switzerland: WHO Library, 2005),

7 Wikipedia, Genetically Modified Food, diakses pada 17 Oktober 2014, http://en.wikipedia.org/wiki/Genetically_modified_food.

8 Wan Jasimah Wan Mohammed Radzi, "Makanan Ubah Suaian Genetik".

$9 \quad$ Kamus Dewan Edisi Keempat, 1040. 
mengelakkan berlaku kemusykilan dalam masyarakat berkaitan dengan status makanan tersebut.

Allah SWT telah menetapkan prinsip yang menjadi tanda aras bagi menentukan status sesuatu makanan di dalam al-Quran sama ada ia halal atau haram. Sebagaimana firman Allah SWT:

Terjemahan: Dan janganlah kamu berdusta dengan sebab apa yang disifatkan oleh lidah kamu: "Ini halal dan ini haram", untuk mengada-ngadakan sesuatu yang dusta terhadap Allah; sesungguhnya orang-orang yang berdusta terhadap Allah tidak akan berjaya.

\section{(al-Naḥl 16:116)}

Ayat di atas menerangkan berkaitan salah satu dari budaya zaman jahiliyyah yang berkembang pada zaman itu, sebelum datangnya Nabi SAW. Masyarakat jahiliyyah pada zaman itu mengharamkan dan menghalalkan sesuatu tanpa meneliti dan merujuk kepada wahyu Allah. Sedangkan, mereka mendakwa sebagai para pengikut ajaran Nabi Ibrahim AS. Sesunggunya Allah SWT melarang keras dari mengikut apa yang telah dilakukan oleh masyarakat pada zaman itu. Justeru, kita pada zaman ini mesti mengkaji dan meneliti sebelum membuat sesuatu hukum agar tidak tergolong dalam golongan yang dinyatakan dalam ayat di atas.

Berikut merupakan garis panduan dalam bentuk modul yang ditetapkan bagi makanan ubah suai genetik agar ia menepati prinsip-prinsip makanan halal di Malaysia:

\subsection{Sumber asas kepada penghasilan GMF}

Umat Islam telah diarahkan oleh Allah SWT agar menggunakan sumber-sumber yang baik dan bersih dalam semua urusan kehidupan mereka termasuklah dalam urusan makan dan minum mereka. ${ }^{10}$ Sumber utama makanan adalah dari haiwan, tumbuhtumbuhan, bahan kimia dan mikro-organisma dan diantaranya ada yang halal dan haram. Oleh itu, perlu diberi penelitian yang khusus

10 Wahbah Ibn Mușțafã al-Zuhaylī, Tafsìr al-Munīr (Dimasyq: Dār alFikr, 1998), 121. 
berkaitan dengan sumber makanan yang diambil bertujuan untuk dijadikan sebagai GMF yang bertepatan dengan hukum syarak.

\section{a. Sumber GMF yang berasaskan haiwan darat}

Haiwan yang hidup di daratan dikenali sebagai al-hayawān albārriyah, yang bermaksud yang hanya dapat hidup di daratan sahaja. ${ }^{11}$ Secara dasarnya haiwan darat yang halal dimakan mestilah disembelih terlebih dahulu sebelum dimakan malah bukan sekadar itu sahaja bahkan adalah menjadi salah satu syarat untuk membolehkan haiwan tersebut dimakan ialah dengan menyebut nama Allah tanpa mensyirikkanya. Allah SWT berfirman:

Terjemahan: Maka makanlah (haiwan-haiwan halal yang telah disembelih) yang disebut nama Allah ketika proses penyembelih (dilakukan), jika kamu beriman kepada ayat-ayatnya.

$$
\text { (al-An‘ām 6:118) }
$$

Ayat di atas dengan jelas menyatakan bahawa setiap sumber makanan yang boleh dimakan oleh manusia adalah halal, suci dan bersih selagi sumber makanan tersebut tidak terdapat sebarang tanda ataupun bukti yang menyatakan ia adalah dari sumber yang haram. Selain itu, makanan itu juga mestilah makanan yang tidak memberi kesan yang memudaratkan kesihatan dan nyawa orang yang memakannya. ${ }^{12}$ Islam melarang keras sesiapa sahaja yang cuba untuk mengharamkan sesuatu perkara yang tidak diharamkan oleh Allah SWT dan Rasul-Nya. Walau bagaimanapun, hukum dan syarat penyembelihan ini tidaklah bersifat mutlak (umum) sehingga menghalalkan semua jenis haiwan di muka bumi ini untuk dimakan dan dimanfaatkan oleh umat Islam dalam pelbagai perkara. ${ }^{13}$

11 Wahbah Ibn Muștafā al-Zuhaylī, al-Figh al-Islāmī wa Adillatuh (Dimasyq: Dār al-Fikr, 1997), 9:2793.

12 Al-Qurțubī, al-Jāmī' li Aḥkām al-Qur'ān, 7:111.

13 Wahbah al-Zuhaylī, Ușūl al-Fiqh al-Islāmī (Dimasyq: Dār al-Fikr, 1986), 1:208. 


\section{b. Sumber GMF yang berasaskan haiwan air}

Manakala haiwan air pula bermaksud hidupan yang hidup di dalam air sahaja sama ada laut atau sungai seperti ikan, udang, ketam dan sotong. Haiwan ini lebih dominan di dalam air dan tidak mampu untuk hidup di daratan. ${ }^{14}$ Allah SWT berfirman:

Terjemahan: Dihalalkan untuk kamu semua haiwan buruan daripada laut dan semua makanan yang terdapat dalam laut sebagai bekalan bagi kamu dan juga orang yang berada dalam pelayaran. Namun begitu, diharamkan ke atas kamu memburu semua jenis haiwan darat selagi kamu masih berada dalam ihram. Oleh itu bertakwalah kepada Allah, kerana kepada-Nya (Allah sahajalah) kamu akan dihimpunkan.

(al-Mā'idah 5:96)

Ayat di atas membuktikan bahawa semua hidupan air adalah halal untuk dimakan dan diambil manfaat daripadanya. Semua produk makanan GMF yang berasaskan DNA haiwan air adalah halal dimakan oleh umat Islam selagi tidak mendatangkan kemudaratan kepada manusia sama ada untuk jangka masa pendek atau panjang. Terdapat banyak dalil sama ada daripada al-Quran mahupun al-Sunnah yang menyokong kepada penentuan hukum sedemikian. ${ }^{15}$

JAKIM juga dalam Muzakarah Jawatankuasa Fatwa Majlis Kebangsaan Bagi Hal Ehwal Ugama Islam Malaysia Kali ke95 yang bersidang pada 16-18 Jun 2011 turut menghalalkan produk-produk makanan ubah suai genetik (GMF) yang berasaskan hidupan air seperti ikan dan seumpamanya selagi tidak memudaratkan manusia. ${ }^{16}$ Oleh itu, kita sebagai manusia yang mempunyai akal haruslah mengenal pasti dan juga membuat

\footnotetext{
14 Al-Zuhaylī, al-Fiqh al-Islāmī wa Adillatuh, 9:2780.

15 Al-Qurțub̄i, al-Jāmō' li Ahkām al-Qur'àn, 3:240.

16 Jabatan Kemajuan Islam Malaysia, Portal Rasmi Fatwa Malaysia, diakses pada 8 Julai 2014, http://www.e-fatwa.gov.my/fatwakebangsaan/hukum-memakan-makanan-terubahsuai-genetikgenetic-modified-food.
} 
kajian agar ia tidak mendatangkan kemudaratan kepada kesihatan dan nyawa manusia. ${ }^{17}$

\section{c. Sumber GMF yang berasaskan tumbuhan}

Semua jenis tumbuh-tumbuhan dan hasilnya adalah halal kecuali yang berbisa, beracun, memabukkan, membahayakan kesihatan manusia serta yang dihasilkan oleh proses bioteknologi moden yang bersumberkan dari bahan yang haram seperti ganja dan seumpamanya. Allah SWT telah berfirman:

Terjemahan: Dan Dialah yang menjadikan kebunkebun yang berjunjung dan yang tidak berjunjung, pohon kurma, tanam-tanaman yang bermacammacam buahnya, zaitun dan delima yang serupa (bentuk dan warnanya) dan tidak sama (rasanya). Makanlah dari buahnya (yang bermacam-macam itu) bila dia berbuah, dan tunaikanlah haknya di hari memetik hasilnya (dengan disedekahkan kepada fakir miskin); dan janganlah kamu berlebih-lebihan. Sesungguhnya Allah tidak menyukai orang yang berlebih-lebihan.

$$
\text { (al-An'ām 6:141) }
$$

Seterusnya ialah bahan semula jadi seperti mineral, air dan lain-lain. semua bahan semula jadi adalah halal ecuali yang beracun, memabukkan dan membahayakan kesihatan manusia dan bercampur dengan benda-benda najis.

\subsection{Asas Kebersihan Dalam Penghasilan Makanan Ubah Suai Genetik (GMF)}

Islam adalah agama yang amat menitikberatkan kebersihan. Justeru, kebersihan merupakan salah satu aspek penting dalam ciri-ciri makanan bagi orang Islam dan ia meliputi pelbagai aspek bermula dari kebersihan diri, pakaian, peralatan dan kawasan pemprosesan atau tempat membuat makanan. Tujuannya ialah

17 Musfirah Syahida Mohamad et al., "Keselamatan Makanan Menurut Perspektif Islam: Kajian Terhadap Pengambilan Makanan Berisiko," Jurnal Fiqh 12 (2015), 1-28. 
untuk menjamin agar makanan yang dihasilkan adalah suci dan tidak membahayakan kepada kehidupan manusia. Allah SWT berfirman:

Terjemahan: Dan ia menghalalkan bagi mereka segala benda yang baik, dan mengharamkan kepada mereka segala benda yang buruk (kotor).

(al-A'rāf 7:157)

Allah mengarahkan umat Islam agar menggunakan sumber yang baik dan bersih dalam semua urusan kehidupan mereka termasuklah dalam urusan makan dan minum mereka. Ayat ini secara tidak langsung mengharamkan semua jenis makanan, minuman, barangan kegunaan harian yang bersifat kotor, jijik dan najis. Ibn 'Abbās menyifatkan daging khinzir, darah yang mengalir, bangkai, arak dan semua perkara yang diharamkan dalam Islam sebagai al-khabā'ith. Al-Rāzī mendefinisikan alkhabā'ith sebagai semua perkara yang kotor dan jijik oleh tabiat manusia sama ada makanan, minuman, hiasan dan sebagainya. ${ }^{18}$

Manakala al-țayyibāt sebagai semua perkara yang halal dan bersih serta dianggap baik oleh tabiat manusia, termasuklah makanan, minuman dan seumpamanya. Kebersihan merupakan sesuatu yang mustahak dan penting dalam agama Islam sehingga Nabi Muhammad SAW menyifatkannya sebagai antara unsur keimanan yang sangat penting. Premis pemprosesan, penyediaan dan penjulaan makanan perlu mengambil berat soal kebersihan bagi mengelakkan dari mengundang kepada haiwan yang kotor dan memudaratkan seperti lalat, ulat, tikus dan cicak. Peralatan yang digunakan juga mesti dan dicuci seberapa kerap yang boleh.

Segala jenis najis seperti khinzir, darah dan tahi adalah haram dijadikan bahan makanan. Begitulah juga dengan bahanbahan suci yang terkena najis (mutanajjis) seperti air kumbahan, makanan yang bercampur dengan najis 'ain. Sesetengah bahan najis seperti alkohol, lemak dan DNA haiwan haram telah pun digunakan secara meluas dalam proses penghasilan produk GMF. Perlu diambil perhatian bahawa bahan yang tidak suci kekal sebagai najis sehinggalah ia disucikan mengikut kaedah-kaedah

'Abd Allāh Ibn 'Umar Ibn al-Hasan al-Rāzì, al-Tafsīr al-Kabīr (Bayrūt: Dār Iḥyā' al-Turāth, t.th), 44. 
yang diiktiraf syarak. Menurut Ibn Nujaym terdapat lima belas kaedah untuk menyucikan najis. Antaranya ialah air mutlak, api, samak, penyembelihan, tanah atau melalui teknik istiḥālah tāmmah. ${ }^{19}$

\subsection{Asas Keselamatan Dalam Makanan Ubah Suai Genetik (GMF)}

Memelihara nyawa dan kehidupan adalah merupakan sebahagian daripada tuntutan Islam. Atas tuntutan tersebut, Allah SWT telah menegaskan dalam al-Quran:

Terjemahan: Dan janganlah kamu membunuh diri seseorang manusia yang diharamkan oleh Allah membunuhnya kecuali dengan alasan yang benar.

$$
\text { (al-Isrā' 17:33) }
$$

Berdasarkan kepada ayat di atas, al-Qurțub $\bar{i}^{20}$ menegaskan sesiapa sahaja yang mengabaikan keselamatan diri sama ada yang berbentuk nyawa atau kesihatan adalah berdosa kerana dia telah meniggalkan perkara yang dituntut dalam Islam. Sabda Nabi SAW:

$$
\text { لا ضرر ولا ضرار }
$$

Terjemahan: Tidak ada mudarat dan tidak boleh melakukan kemudaratan.

Namun agama Islam membenarkan umatnya memakan makanan yang diharamkan sekiranya seseorang itu berada dalam keadaan darurat. Sebagaimana firman Allah SWT:

Terjemahan: Dan tidak ada sebab bagi kamu, (yang menjadikan) kamu tidak mahu makan dari (sembelihan binatang-binatang halal) yang disebut nama Allah ketika menyembelihnya, padahal Allah telah menerangkan satu persatu kepada kamu apa yang diharamkanNya atas kamu. Kecuali sesuatu

19 Ibn Nujaym, Zayn al-Dīn Ibn Ibrāhim, al-Asybāh wa al-Naẓā'ir fì Madhhab Hanafì (Bayrūt: Dār al-Kutub al-'Ilmiyyah, 1980), 166.

20 Muhammad Ibn Aḥmad al-Qurțub̄i, al-Jāmi ' li Ahkām al-Qur'ān (al-Qāhirah: Dār al-Kitāb al-'Arabī, 1967), 4:110. 
yang kamu terpaksa memakannya ketika darurat.

$$
\text { (al-An'ām 6:119) }
$$

Walau bagaimanapun, kelonggaran yang dibenarkan itu tidaklah bersifat mutak (terbuka), tetapi ia lebih bersifat sementara hingga keadaan darurat sudah tiada lagi. Kaedah fiqh turut menegaskan:

$$
\text { ما أبيح للضرورات يقدر بقدرها }
$$

Terjemahan: Semua perkara yang diharuskan (pada asalnya haram) ketika darurat hendaklah diambil mengikut kadar yang sepatutnya (minimum tanpa berlebihan). ${ }^{21}$

Sehubungan itu, setiap produk GMF yang berasaskan haiwan khususnya yang haram dimakan boleh dimakan sekiranya dalam keadaan darurat sehingga memudaratkan manusia namun hendaklah dimakan dalam kadar yang sepatutnya.

Dalam konteks Malaysia yang kian pesat bertambah makanan GMF dihasilkan sebagai suatu langkah bagi memenuhi keperluan dan permintaan masyarakat disamping meningkatkan kualiti dan kuantiti makanan. Oleh itu, makanan atau bahan makanan yang berasaskan bioteknologi mesti memenuhi syarat yang telah ditetapkan di bawah Bahagian Keselamatan \& Kualiti Makanan Malaysia.

Bahagian Keselamatan dan Kualiti Makanan (BKKM) bertanggungjawab memastikan keselamatan dan kualiti makanan melalui Program Keselamatan dan Kualiti Makanan bagi seluruh Wilayah Persekutuan Kuala Lumpur dan Putrajaya. Perlaksanaan ini mengikut peruntukan, prosedur dan kod amali yang ditetapkan di bawah Akta Makanan 1983 dan Peraturanperaturan Makanan 1985, Peraturan Kebersihan Makanan 2009 dan Peraturan Makanan (Pengeluaran Sijil Kesihatan bagi Eksport Ikan dan Hasilan Ikan ke Kesatuan Eropah) 2009. Jabatan ini

21 'Abd al-Raḥmān Ibn Abī Bakr al-Suyūṭ̂̄, al-Asybāh wa al-Naẓā'ir fì Madhhab al-Syāfí̀ (Bayrūt: Dār al-Kutub al-'Ilmiyyah, 2001), 1:170. 
akan bersidang dalam Mesyuarat Penyelaras Kebangsaan untuk Makanan dan Pemakanan. ${ }^{22}$

Bahagian Keselamatan \& Kualiti Makanan Malaysia menggalakkan pengusaha produk berasaskan bioteknologi berbincang dengan mereka sebelum memasarkan produk tersebut. Perkara ini amat membantu dalam menentukan langkah-langkah yang perlu diambil untuk memastikan makanan yang dihasilkan melalui proses bioteknologi moden ini selamat dan sah disisi undang-undang dan agama.

Pengusaha mesti meletakkan ciri-ciri keselamatan merangkumi bahan asas dalam proses ubah suai genetik, bahan tersebut berkemungkinan mengandungi toksik atau alahan, dan juga perbandingan tahap nutrisi dalam makanan yang telah diubah suai genetik dengan produk yang dihasilkan melalui proses penanaman biasa. Proses penilaian selesai apabila pihak BKKM benar-benar berpuas hati dengan langkah-langkah keselamatan yang di ambil dan tidak ada sebarang keraguan dan persoalan yang berkaitan dengan keselamatan atau isu-isu berkaitan.

\subsection{Modul Penentuan Hukum Makanan Ubah Suai Genetik (GMF)}

Melalui bimbingan al-Quran dan al-Sunnah umat Islam telah didedahkan dengan garis panduan yang jelas dalam mengenal pasti status hukum jenis-jenis haiwan yang wujud. Umat Islam hanya dibenarkan untuk mengambil manfaat dari haiwan yang halal sahaja tidak kira sama ada ia hidup atau mati.

Namun, makanan GMF adalah sesuatu yang baharu dan memerlukan kepada hukum yang baharu. Produk GMF mestilah dianalisis dengan teliti sebelum ditentukan statusnya sama ada ia halal atau haram. Secara umumnya, Islam menetapkan selagi tiada bukti yang menunjukkan kepada pengharaman maka hukum asalnya adalah harus dan halal. Oleh sebab itu, kaedah fiqh jelas sekali menegaskan:

22 JKNKL, Portal Rasmi Jabatan Kesihatan Wilayah Persekutuan Kuala Lumpur Dan Putrajaya, diakses pada 9 Julai 2014, http://jknkl.moh. gov.my/web/guest/bahagian-keselamatan-dan-kualiti. 


$$
\text { الأصل في الأشياء الإباحة حتى يدل الدليل علي التحريم }
$$

Terjemahan: Asal pada sesuatu itu adalah harus (halal) sehinggalah terdapat dalil (bukti) yang mengharamkannya. ${ }^{23}$

Oleh itu, hukum semasa bagi makanan GMF mesti ditentukan bagi mengelakkan umat Islam memakan makanan yang tidak sah disisi syarak malah memabawa kepada kemudharatan diri. Muhammad Sulaymān al-Ashqar menegaskan bahawa penghasilan sesuatu produk makanan atau perubatan perlu diambil berat oleh pihak berkuasa Islam. ${ }^{24} \mathrm{Di}$ samping itu, keperluan kepada pengguna bioteknologi secara bertanggungjawab mesti ditekankan agar sesuai dengan peranna manusia sebagai khalifah yang bertanggungjawab di muka bumi ini. Justeru, pihak berwajib seperti Bahagian Perancangan \& Penyelidikan JAKIM dan Bahagian Hab Halal JAKIM akan bersidang dan berbincang mengenai hukum makanan GMF. Melalui perbincangan ini, satu keputusan akan dibuat sama ada makanan GMF dalam kategori halal atau haram.

\subsubsection{Prinsip Penentuan Hukum Makanan Ubah Suai Genetik (GMF)}

Kajian berhubung dengan hukum produk GMF perlu dikaji secara mendalam. Selain itu, kajian terhadap pandangan fuqaha' mengenai hukum sesuatu makanan juga mesti dilakukan secara terperinci dan teliti. Melalui kajian yang dilakukan, terdapat enam prinsip penentuan hukum makanan ubah suai genetik dapat digariskan secara tersusun bagi memudahkan proses penentuan hukum produk GMF pada masa akan datang. Menerusi prinsipprinsip tersebut, para ulama, saintis dan para penyelidik masa akan datang boleh menjadikannya sebagai garis panduan utama

23 Ibn Nujaym, Zayn al- 'Ābidīn, al-Asybah wa al-Nazạ 'ir 'alā Madhhab Abī Hanīfah al-Nu'mān (Bayrūt: Dār al-Kutub al-'Ilmiyyah, 1985), 1:190 \& al-Suyūṭī, al-Asybah wa al-Nazā 'ir, 60.

24 Muhammad Sulaymān al-Asyqar, Abhàth Ijtihādiyyah fì al-Fiqh alTỉbb (Bayrūt: Dār al-Nafā'is, 2006), 93. 
dalam menentukan sesuatu hukum berkaitan dengan produk GMF. Prinsip-prinsip tersebut adalah:

\section{a. Prinsip Halal Haram Haiwan}

Sesuatu produk GMF yang bersumberkan DNA haiwan mestilah menepati kehendak syarak. Sekiranya haiwan yang menjadi sumber asas kepada produk GMF itu haiwan yang haram dimakan, maka ia akan turut memberi kesan terhadap hukum produk GMF yang dihasilkan itu. Sekiranya, ia berasal daripada haiwan yang halal dimakan, maka hukum produk GMF tersebut adalah halal dimakan. Atas dasar itu, setiap usaha yang ingin dilakukan dalam menghasilkan produk GMF mestilah terlebih dahulu merujuk kepada jenis-jenis haiwan yang ingin dijadikan asas kepada produk baharu tersebut. Setiap kategori haiwan yang hidup di muka bumi ini mempunyai hukum tersendiri. Justeru, prinsip halal haram haiwan perlu diambil perhatian sebagai langkah berhatihati dalam menghasilkan produk makanan yang bersifat semasa untuk umat Islam.

\section{b. Prinsip Penyembelihan Haiwan}

Para fuqaha saling berselisih pandangan dalam mentakrifkan perkataan al-dhakāh. Ini kerana berlakunya perbezaan yang agak ketara dalam kalangan mereka bagi memahami maksud yang terdapat dalam nas atau dalil sama ada daripada al-Quran, al-Sunnah dan amalan para sahabat RA dalam melakukan proses penyembelihan. ${ }^{25}$ Dalam penyembelihan, wajib memutuskan empat urat penting, iaitu halqūm (urat pernafasan), marī' (saluran makanan) dan wadajayn (dua pembuluh darah).

Dalam konteks ini, mazhab Hanafi berpendapat proses penyembelihan tidak akan sempurna sehinggalah empat urat penting pada leher haiwan berkenaan putus sepenuhnya. Manakala mazhab Maliki berpendapat bahawa sesuatu penyembelihan mestilah dilakukan oleh orang Islam dengan memutuskan tiga daripada empat urat penting yang terdapat pada bahagian leher haiwan tersebut, iaitu halqūm dan wadajayn.

25 'Abd Allāh Muḥammad al-Ṭarīqī, Aḥkām al-Dhabā'iḥ wa al-Luhūm al-Mustawradah fi al-Syarī'ah al-Islämiyyah (Bayrūt: Mu'assasah al-Risālah, 1983), 62 . 
Mazhab Syafii pula berpendapat proses penyembelihan mestilah dilakukan dengan hanya memutuskan urat halqūm dan marì' bagi haiwan yang mampu disembelih. Manakala bagi haiwan yang tidak mampu disembelih disebabkan sifatnya yang liar atau ditimpa sebarang musibah, maka dibolehkan ia dibunuh dengan apa cara sekalipun sehingga membawa kepada kematian. ${ }^{26}$ Manakala bagi mazhab Hanbali pula, proses penyembelihan hanya dilakukan ke atas haiwan daratan yang mampu disembelih dan halal dimakan oleh umat Islam. Namun, terdapat haiwan daratan yang bersifat liar dan sukar untuk disembelih, maka cara untuk mematikannya sudah memadai dengan menikam al-'aqr pada bahagian-bahagian tubuh haiwan tersebut. ${ }^{27}$

Setelah dilakukan analisis terhadap dasar-dasar penyembelihan oleh empat mazhab tersebut mendapati pendekatan yang dibawa oleh mazhab Hanbali hampir kepada kesempurnaan. Perkara yang sama turut diperakui oleh sebahagian ulama kontemporari seperti 'Abd Allāh Muḥammad al-Ṭarīqi. ${ }^{28}$

\section{c. Prinsip Tidak Besrsumberkan Najis}

Kebersihan merupakan salah satu aspek yang penting dalam Islam dan aspek ini juga diterapkan dalam menghasilkan sesuatu produk GMF. Terdapat pelbagai sumber yang boleh diklasifikasikan sebagai najis, antaranya; bangkai, iaitu haiwan yang mati tanpa disembelih mengikut hukum syarak. Bagi mengelakkan sesuatu haiwan dihukum sebagai bangkai terdapat syarat-syarat yang telah ditetapkan oleh syarak yang perlu diikut.

Selain itu, darah juga merupakan sumber yang sering diguna pakai oleh manusia untuk pemprosesan makanan dan darah ada dua jenis, iaitu al-masfuh (darah yang mengalir) dan darah yang tidak mengalir (beku). Kedua-duanya mempunyai hukum yang berbeza. Bagi darah yang mengalir fuqaha empat mazhab telah bersepakat mengharamkan penggunnaanya dalam semua produk

26 Sulaymān Ibn 'Umar Ibn Muhammad al-Bujayrimī, Hāsyiyyah alBajayrim̄̄ 'alā Syarh Minhāj al-Ṭālibīn (Bayrūt: al-Maktabat alIslāmiyyah, t.th), 285.

27 Manșūr Ibn Yūnus Ibn Idrīs al-Bahūtī, Kasyaf al-Qinā ‘ 'an Matn alIqnā' (Dimasyq: Dār al-Fikr, 1402H), 203.

28 Al-Ṭarīqī, Ahkām al-Dhabā'ih, 70. 
makanan sama ada yang bersifat klasik ataupun moden. Berbeza dengan darah yang tidak mengalir di mana Nabi SAW sendiri telah menghalalkan dua jenis darah yang bersifat tidak mengalir, iaitu hati dan limpa untuk dimakan. Al-Zuhaylī turut menambah bahawa darah yang melekat pada daging haiwan turut halal dimakan kerana ia termasuk dalam perkara 'umūm balwā (tidak boleh dielakkan), di samping ia juga turut diklasifikasikan sebagai tidak mengalir. ${ }^{29}$ Oleh itu, penggunaan darah yang tidak mengalir dalam pemprosesan produk GMF adalah halal disisi syarak.

\section{d. Prinsip Istiḥālah Tāmmah}

Istihāalah mempunyai pertalian yang sangat erat dengan sapek kebersihan dan kesucian (tahārah) khususnya dalam isu makanan GMF. Nabi Muhammad SAW menyifatkan kebersihan antara unsur keimanan yang sangat penting bagi umat Islam. Kepentingan proses istihālah tämmah dalam menghasilkan produk makanan GMF berasaskan haiwan amat penting kerana fungsinya sebagai metode penyucian najis atau bahan yang terkena najis. Proses ini mampu menghilangkan sifat najis daripada sesuatu jisim setelah penukarannya kepada jisim yang baharu dan berbeza secara keseluruhan daripada jisim asal.

Proses istihālah boleh berlaku sama ada secara semula jadi atau dengan campur tangan manusia, menukarkan najis kepada bahan yang suci. Dalam konteks lain, bahan yang asalnya haram diguna pakai, kini dapat dimanfaatkan secara optimum dalam pelbagai indsutri. Contohnya arak adalah haram diminum atau dimasukkan ke dalam masakan. Akan tetapi, setelah berlakunya proses istihālah yang sempurna sehingga bertukar sifatnya kepada cuka, maka hukumnya berubah menjadi halal sama ada untuk minuman atau makanan. Tambahan pula, apabila sifat-sifat arak (najis) seperti bau, rasa, warna serta idenitinya juga tidak dapat lagi dikesan atau dikenal pasti dalam cuka. Oleh itu, cuka dihalalkan makan dan dimanfaatkan dalam semua perkara.

Proses istihālah yang berlaku dalam produk GMF dikategorikan sebagai halal sekiranya ia berlaku secara istihālah tāmmah. Oleh yang demikian, penentuan hukum bagi isu produk GMF mestilah dibuat berdasarkan kes-kes yang dikaji secara satu persatu. Ini

29 Al-Zuhaylī, Tafsīr al-Munīr, 7:80. 
bermakna hukum GMF hanya boleh ditentukan apabila kajian membuktikan zat dan kesan najis 'ayn yang terdapat padanya benar-benar sudah hilang. Sekiranya ia benar-benar suci daripada kesan najis, maka tidak salah untuk menghalalkan produk GMF berkenaan.

\section{e. Prinsip Maṣlaḥah dan Mafsadah}

Para ulama fiqh telah menggambarkan mașlahah dengan pelbagai maksud, iaitu gambaran bagi konsep mendapatkan manfaat atau menolak segala mudarat. ${ }^{30}$ 'Izz al-Dīn 'Abd al-Salām pula menjelaskan bahawa ia dapat dijelaskan menerusi dua cara. Pertama; iaitu secara haqīq $\bar{l}$, iaitu keseronokan dan kelazatan, dan kedua; secara majāz $\bar{l}$, iaitu sebab yang boleh membawa kepada keseronokan dan kelazatan. ${ }^{31}$ Al-Shațibī turut mendefinisikan mașlahah sebagai proses untuk memastikan kelangsungan dan kesempurnaan kehidupan manusia dalam semua aspek. ${ }^{32}$ Terdapat juga sebahagian fuqaha mentakrifkan mașlaḥah sebagai manfaat yang digunakan oleh syarak untuk manusia bagi memelihara agama, jiwa, akal, keturunan dan harta. ${ }^{33}$

Ulama-ulama bersepakat bahawa mașlahah yang menepati kehendak syarak sahaja yang akan diterima pakai. Mașlahah tersebut pula mestilah meliputi lima perkara terpenting yang perlu dipelihara iaitu penjagaan agama, nyawa, akal, keturunan dan harta. ${ }^{34}$ Manakala mafsadah pula adalah suatu konsep yang bertentangan dengan mașlahah diertikan sebagai manfaat yang dikehendaki oleh syarak bagi manusia daripada pemeliharaan agama, nyawa, akal, keturunan dan harta. Oleh itu, mafsadah ialah

30 Muhammad Ibn Muhammad al-Ghazālī, al-Mustașfā fì 'Ilm al-Ușūl, (al-Qāhirah: Dār al-Harāmayn, 1413H), 1:286.

31 Abū Muhammad 'Izz al-Dīn 'Abd al-'Azīz bin 'Abd al-Salām alSulāmī, al-Qawā 'id al-Kubrā, al-Mawsū' 'ah bi Qawā 'id al-Ahkām fì Ișlāḥ al-Anām (Dimasyq: Dār Qalam, 2000), 36.

32 Ibrāhim Ibn Mūsā al-Syațib̄i, al-Muwāfaqāt fì Ușūl al-Syarī'ah (Bayrūt: Mu'assasat al-Risālah, 1997), 2:26.

33 Muḥammad Aḥmad Burkab, al-Mașālih al-Mursalah wa Atharuhā fì Murūnah Fiqh al-Islāmī (Bayrūt: Dār Ibn Kathīr, t.th), 30.

34 Burkab, al-Mașālih al-Mursalah wa Atharuhā. 
kemudaratan yag ditolak oleh syarak kerana kesan negatifnya terhadap agama, jiwa, akal, nasab dan harta. ${ }^{35}$

Islam sangat memelihara mașlaḥah umatnya dalam semua aspek kehidupan termasuklah berhubung isu makanan GMF. Jika dikaji, setiap arahan dan larangan yang terdapat dalam syariat Islam tidak pernah terlepas daripada memelihara Maqāșid alSyarī'ah manusia sekaligus mencegah segala jenis mafsadah dan kemudaratan. Lebih jelas lagi, Allah telah mengarahkan agar umat Islam mencari makanan yang baik, di samping menjauhi segala makanan yang haram kerana kekotorannya, sifatnya yang beranajis dan berbahaya. ${ }^{36}$ Tujuannya adalah untuk memelihara kemaslahatan nyawa manusia daripada kebinasaan ${ }^{37}$ dan ia adalah intipati sebenar Maqāșid al-Syarī'ah yang wajib dipelihara. ${ }^{38}$ Namun, tidak dinafikan bahawa setiap mașlahah mestilah menepati syarat-syarat yang telah ditetapkan oleh Islam agar tidak digunakan pada jalan yang salah.

\section{f. Prinsip Darurat dalam Penentuan Hukum GMF}

Darurat merupakan satu keadaan yang sangat mendesak sehingga memaksa sesiapa sahaja untuk melakukan perkara-perkara yang diharamkan bagi meneyelamatkan agama, jiwa, akal, keturunan dan harta.$^{39}$ Berhubung dengan isu ini, para fuqaha telah bersepakat menghalalkan sesiapa sahaja yang berada dalam keadaan tersebut melakukan perkara-perkara haram bagi memelihara lima maqasid tersebut. ${ }^{40}$

35 Muhammad Ṭāhir Ibn 'Ashūr, Maqāṣid Syarī'ah al-Islāmiyyah (alQāhirah: Dār al-Salam, 2007), 63.

36 Norhidayah Pauzi et al., "Haiwan Jallālah dari Persepektif Islam: Analisis Fatwa Malaysia dan Negara Brunei Darussalam," Jurnal Fiqh 12 (2015), 57-78.

37 Aḥmad Ibn 'Abd al-Raḥīm al-Dahlawī, Hujjat Allāh al-Bālighah (alQāhirah: Dār al-Kutub al-Hadīth, t.th), 2.

38 Muḥammad Sa'īd Ramaḍān al-Būṭ̂, Dawābiṭ al-Maṣlahah fì alSyarī'ah al-Islāmiyyah (Bayrūt: Mu'assasat al-Risālah, 2001), 38.

39 Al-Būțī, Dawābiṭ al-Maṣlahah.

40 Muhammad Ibn Ab̄̄ al-'Abbās Aḥmad Ibn Hamzah Ibn Syibāb alDīn al-Ramlī, Nihāyat al-Muhtāj ilā Syarh al-Minhāj fì al-Fiqh 'alā Madhhab al-Imām al-Syāfi 'i (Bayrūt: Dār al-Kutub al-'Ilmiyyah, 1987), 144. 
Namun begitu, pendekatan darurat sentiasa digunakan bagi menghalalkan sesuatu yang haram. Perkara yang sama turut berlaku dalam penentuan hukum GMF. Ini kerana terdapat pelbagai andaian bahawa GMF amat diperlukan sehingga mencapai tahap darurat. Sehubungan itu, bagi mengelak perkara-perkara haram dihalalkan dengan sewenang-wenangnya, maka penggunaan prinsip darurat ini mestilah menepati syarat-syarat darurat seperti yang telah ditetapkan oleh Islam.

\subsection{Keperluan Logo Halal bagi Produk Makanan Ubah Suai Genetik (GMF)}

Sijil halal merupakan salah satu pengiktirafan yang penting bagi sesuatu produk yang hendak dipasarkan kepada umat Islam. Sijil ini dikeluarkan oleh badan yang diiktiraf oleh kerajaan. Di malaysia, JAKIM merupakan badan yang bertanggungjawab dalam mengeluarkan sijil halal di Malaysia. Manakala, Brunei Darussalam meletakkan tanggungjawab tersebut kepada Majlis Agama Islam Negara Brunei Darussalam. ${ }^{41}$ Dengan adanya sijil halal tersebut menunjukkan bahawa sesuatu produk itu telah diiktiraf oleh institusi agama yang bertanggungjawab setelah dilakukan kaji selidik dan pemeriksaan yang teliti dari semua aspek.

Di Malaysia, penggunaan penunjuk 'Halal', 'Ditanggung Halal' atau sebarang perbahasan yang boleh membawa erti bahawa orang Islam boleh memakan dan menggunakannya akan menujukkan hasil keluaran premis pemprosesan, penyediaan dan penjualan adalah halal bagi orang Islam. ${ }^{42}$ Menurut KPDNKK, ${ }^{43}$ Perintah Perihal Dagangan (Perakuan Dan Penandaan Halal) 2011 hanya memperuntukkan Jabatan Kemajuan Islam Malaysia (JAKIM) dan Majlis Agama Islam bagi Negeri-Negeri (MAIN) masing-masing dilantik menjadi pihak berkuasa berwibawa untuk

41 The Religious Council Negara Brunei Darussalam (TRCNBD). Halal Food: Piawai Brunei Darussalam PBD 24: 2007, ed ke-1 (Majlis Agama Islam: Brunei Darussalam, 2007)

42 Jabatan Kemajuan Islam Malaysia, Portal Rasmi Halal Malaysia, diakses pada 8 Julai 2014, http://www.halal.gov.my/ v3/index.php/ ms/mengenai-pensijilan-halal/ takrifan-halal.

43 Jabatan Kemajuan Islam Malaysia, Portal Rasmi Halal Malaysia. 
memperaku bahawa makanan, barang-barang atau perkhidmatan yang berhubung dengan makanan atau barang-barang itu adalah halal mengikut Perintah Perihal Dagangan (Takrif Halal) 2011.

Manakala di Singapura, logo halal dikeluarkan oleh Majlis Ugama Islam Singapura (MUIS) di bawak seksyen 88A di bawah Akta Undang-undang Islam (Cap 3). Setiap produk, perkhidmatan atau aktiviti yang mempunyai logo halal maka ia telah memenuhi syarat undang-undang syarak yang membolehkan umat Islam di Singapura untuk menggunakannya. ${ }^{44}$

\subsection{Keperluan kepada Label Makanan Ubah Suai Genetik (GMF)}

Setelah selesai setiap proses yang disyaratkan dan mendapat taraf sah halal oleh JAKIM seterusnya makanan berasaskan GMF akan dilabel untuk membezakan antara makanan berasaskan bioteknologi dan makanan yang tumbuh atau hidup secara semula jadi.

Di Amerika Syarikat, pihak Food and Drug Administration (FDA) menggalakkan pihak pengusaha untuk meletakkan maklumat yang bermanfaat di atas label dengan mengatakan makanan makanan tersebut telah melalui proses kejuruteraan bioteknologi. Maklumat tersebut dinyatakan bagi mengelakkan dari berlaku salah faham atau percanggahan maklumat. Sebagai tambahan, label tersebut mesti menyatakan fakta tentang bahan asas makanan GMF tersebut. Sebarang makanan GMF yang mempunyai nutrisi berlainan mestilah dinyatakan perbezaannya dengan makanan yang semula jadi. Seterusnya, sekiranya produk GMF itu mempunyai kesan sampingan maka mestilah dicatat di atas label bagi memudahkan pengguna. ${ }^{45}$

44 Majlis Ugama Islam Singapura (MUIS), General Guidelines for the Handling and Processing of Halal Food. MUIS-HC-S001 (MUIS: Singapura, 2005).

45 FDA, U.S Food and Drug Administration, diakses pada 8 Julai 2014, http:/www.fda.gov/food/guidanceregulation/ guidancedocumentsregulatoryinformation/labelingnutrition/ ucm059098.htm 
Di Malaysia, Rang Undang-undang Keselamatan Bio (Kementerian Sumber Asli dan Alam Sekitar) dan pindaan kepada Peraturan Makanan 1985 (Kementerian Kesihatan Malaysia) telah menetapkan sebarang produk makanan yang mengandungi GMOs perlu dilabel sebagai produk yang mengandungi GMOs. Ini selaras dengan undang-undang di negara-negara lain yang dibentuk untuk melindungi pengguna dan alam sekitar.

Mungkin terdapat kesan-kesan GMOs yang tidak diketahui, seperti berpotensi meninggalkan kesan alahan. Dengan melabel, para pengguna akan mengetahui kandungan GMO dalam makanan, dan diharap dapat memberi amaran kepada mereka yang menitikberatkan soal kesihatan. Misalnya, jika gen kacang digunakan dalam GMO, sebahagian besar pengguna yang alah kepada kacang sudah tentu ingin mengetahui kandungan makanan tersebut, dan pelabelan sudah pasti memenuhi keperluan ini.

Pelabelan juga perlu bagi memaklumkan kepada pengguna mengenai kandungan GMO, terutama bagi mereka yang menitikberatkan soal agama, etika dan moral. Misalnya jika gen babi digunakan dalam produk GMF, pengguna Islam perlu dimaklumkan mengenainya melalui label yang sewajarnya. Begitu juga jika gen ikan dimasukkan ke dalam tomato GM, golongan pemakan sayur memerlukan label yang memaklumkan kepada mereka bahawa makanan tersebut mengandungi gen GM bukan pemakan sayur. ${ }^{46}$

\section{Kepentingan Modul Penentuan Hukum Makanan Ubah Suai Genetik (GMF) bagi Umat Islam}

Garis panduan berkaitan dengan penentuan hukum GMF amat dalam memberi kemudahan kepada pihak yang berwajib seperti JAKIM di Malaysia dan organisasi-organisasi Islam di seluruh dunia dalam membuat keputusan berkaitan produk GMF. Dengan adanya garis panduan ini, umat Islam dapat membuat sesuatu keputusan berhubung dengan makanan ubah suai genetik dengan lebih efektif dan teratur.

$46 \quad$ Free Trade Agreement Malaysia Information, "CAP Worries FTA Threatens GM Food Labelling”, diakses pada 8 November 2014, http://www.ftamalaysia.org/ article.php?aid=155. 
Selain itu, garis panduan ini dapat membantu pihak Majlis Fatwa Kebangsaan Malaysia dan Majlis Negeri-negeri di seluruh Malaysia dalam menentukan hukum produk GMF. Isu makanan ubah suai genetik adalah isu yang kompleks dan memerlukan kepada pengkajian yang teliti maka dengan adanya garis panduan ini dilihat dapat membantu para ulama dalam penentuan hukum dengan lebih mudah dan terarah.

Seterusnya, memberi kesan yang besar kepada masyarakat kerana dengan adanya garis panduan ini membolehkan umat Islam menilai sama ada sesuatu makanan itu halal dimakan atau sebaliknya. Ia merupakan usaha untuk memastikan makanan, minuman dan produk yang digunakan umat Islam menepati syariat Islam dan terjamin dari segi kesihatan.

\section{KESIMPULAN}

Kesimpulan yang dapat dibuat oleh penulis berkaitan dengan penentuan hukum GMF adalah ia memerlukan kepada kajian yang teliti dan teratur bagi membolehkan umat Islam memakannya tanpa timbul perasaan ragu-ragu berkenaan status sesuatu produk GMF. Hal ini selari dengan maqasid syariah yang sememangnya jelas untuk memelihara kemaslahatan manusia dengan membuka ruangruang manfaat kepada mereka dan mengangkat kemudaratan. Islam tidak melarang umatnya dari mengikut perkembangan teknologi selagi ia tidak bercanggah dengan hukum syarak. Berdasarkan kepada perbincangan di atas, modul penentuan hukum GMF adalah penting bagi memudahkan pihak-pihak yang berwajib untuk menetapkan hukum bagi produk-produk GMF yang berkembang pesat dan meluas di pasaran. Produk GMF yang dihasilkan melalui teknik kejuruteraan bioteknologi percampuran antara DNA haiwan yang bernajis seperti babi adalah haram dimakan manakala makanan terubah suai genetik yang melibatkan percampuran antara gen-gen haiwan yang suci dan halal dimakan adalah diharuskan oleh syarak. Justeru, umat Islam perlu bijak dalam memilih produk GMF yang halal disisi sarak. Diharap modul ini dapat membantu organisasi-organisasi Islam dalam membuat penentuan hukum berkaitan produk makanan GMF. 


\section{BIBLIOGRAFI}

Anisah Ab Ghani et al. "Penentuan Piawaian Alkohol dalam Makanan yang Dibenarkan dari Perspekif Islam." Jurnal Fiqh 7 (2010), 277-299.

Al-Asyqar, Muhammad Sulaymān. Abhāth Ijtihādiyyah fì al-Fiqh al-Tibb. Bayrūt: Dār al-Nafā' is, 2006.

Al-Bahūtī, Manșūr Ibn Yūnus Ibn Idrīs. Kasyaf al-Qinā' 'an Matn al-Iqnā'. Dimasyq: Dār al-Fikr, 1402H.

Bruce A., Gertz R., Oram C., Suk J., Tait J., Warkup C., \& Whitelaw B.. Animal Cloning and Genetic Modification: A Prospective Study, Genesis Faraday. Scotland: Roslin BioCentre, 2005.

Al-Bujayrimī, Sulaymān Ibn 'Umar Ibn Muḥammad. Hāsyiyyah al-Bajayrim̄̄ 'alā Syarh Minhāj al-Ṭālibìn. Bayrūt: alMaktabat al-Islāmiyyah, t.th.

Burkab, Muḥammad Aḥmad. Al-Mașāliḥ al-Mursalah wa Atharuhā fì Murūnah Fiqh al-Islāmī. Bayrūt: Dār Ibn Kathīr, t.th.

Al-Būṭī, Muhammad Sa'īd Ramaḍān. Dawābiṭ al-Maṣlahah fì al-Syarī'ah al-Islāmiyyah. Bayrūt: Mu'assasat al-Risālah, 2001.

Al-Dahlawī, Aḥmad Ibn ‘Abd al-Rahīm. Hujjat Allāh al-Bālighah. Al-Qāhirah: Dār al-Kutub al-Hadīth, t.th.

FDA. U.S Food and Drug Administration. Diakses pada 8 Julai $2014 . \quad \mathrm{http}: / / \mathrm{www} . f d a . g o v /$ food/guidanceregulation/ guidancedocumentsregulatory information/ labelingnutrition/ucm059098.htm

Free Trade Agreement Malaysia Information. "CAP Worries FTA Threatens GM Food Labelling". Diakses pada 8 November 2014. http://www.ftamalaysia.org/ article.php?aid=155.

Al-Ghazālī, Muḥammad Ibn Muḥammad. Al-Mustaşāa fì 'Ilm alUșūl.Al-Qāhirah: Dār al-Ḥarāmayn, 1413H).

Ibn 'Abd al-Salām Abū Muhammad 'Izz al-Dīn 'Abd al-'Azīz al- 
Sulāmī. Al-Qawā 'id al-Kubrā, al-Mawsū 'ah bi Qawā 'id alAḥkām fì Ișlāḥ al-Anām. Dimashq: Dār Qalam, 2000.

Ibn 'Asyūr, Muhammad Ṭāhir. Maqāṣid Syarī'ah al-Islāmiyyah. Al-Qāhirah: Dār al-Salam, 2007.

Ibn Nujaym, Zayn al-'Ābidīn. Al-Asybah wa al-Nazā'ir 'alā Madhhab Abī Hanīfah al-Nu 'mān. Bayrūt: Dār al-Kutub al'Ilmiyyah, 1985.

Ibn Nujaym, Zayn al-Dīn Ibn Ibrāhim. Al-Asybāh wa al-Nazā 'ir fì Madhhab Hanafí. Bayrūt: Dār al-Kutub al-'Ilmiyyah, 1980.

Jabatan Kemajuan Islam Malaysia. Portal Rasmi Halal Malaysia. Diakses pada 8 Julai 2014. http://www.halal.gov.my/ v3/ index.php/ms/mengenai-pensijilan-halal/ takrifan-halal.

Jabatan Kemajuan Islam Malaysia. Portal Rasmi Fatwa Malaysia. Diakses pada 8 Julai 2014. http://www.e-fatwa.gov.my/ fatwa-kebangsaan/hukum-memakan-makanan-terubahsuaigenetik-genetic-modified-food.

JKNKL. Portal Rasmi Jabatan Kesihatan Wilayah Persekutuan Kuala Lumpur Dan Putrajaya. Diakses pada 9 Julai 2014. http://jknkl.moh.gov.my/web/guest/bahagian-keselamatandan-kualiti.

Kamus Dewan. Edisi ke-4. Kuala Lumpur: Dewan Bahasa dan Pustaka, 2005.

KPDNKK. 2014. Portal Rasmi Kementerian Perdagangan Dalam Negeri, Koperasi dan Kepenggunaan. Diakses pada 8 Julai 2014. http://www.kpdnkk.gov.my/web/guest/pengguna/ penguatkuasaan/tanda-halal.

Majlis Ugama Islam Singapura (MUIS). General Guidelines for the Handling and Processing of Halal Food. MUISHC-S001. MUIS: Singapura, 2005.

Mohd Izhar Ariff Bin Mohd Kashim. Penentuan Hukum Makanan Ubah Suai Genetik (GMF) Berasaskan Haiwan. Bangi: Universiti Kebangsaan Malaysia, 2012.

Musfirah Syahida Mohamad et al. "Keselamatan Makanan Menurut Perspektif Islam: Kajian Terhadap Pengambilan 
Makanan Berisiko.” Jurnal Fiqh 12 (2015), 1-28.

Norhidayah Pauzi et al. "Haiwan Jallālah dari Persepektif Islam: Analisis Fatwa Malaysia dan Negara Brunei Darussalam." Jurnal Fiqh 12 (2015), 57-78.

Al-Qurțubī, Muhammad Ibn Aḥmad. Al-Jāmi' li Ahkām alQur'ān. Al-Qāhirah: Dār al-Kitāb al-'Arab̄i, 1967.

Al-Qurțubī, Muḥammad Ibn Aḥmad. Al-Jāmi' li Ahkām alQur'ān. Dimasyq: Dār al-Fikr, 1998.

Al-Ramlī, Muḥammad Ibn Ab̄̄ al-'Abbās Aḥmad Ibn Ḥamzah Ibn Syibāb al-Dīn. Nihāyat al-Muhtāj ilā Syarh al-Minhāj fì al-Fiqh 'alā Madhhab al-Imām al-Syāfi 'ì. Bayrūt: Dār al-Kutub al-'Ilmiyyah, 1987.

Al-Rāzī, 'Abd Allāh Ibn 'Umar Ibn al-Ḥasan. Al-Tafsīr al-Kabīr. Bayrūt: Dār Iḥyā' al-Turāth, t.th.

Al-Syāribī, Sayyid Quțb Ibrāhim Ḥusayn. Tafsìr fì Zilāl al-Qur'ān. Bayrūt: Dār al-Kutub al-'Ilmiyyah, t.th.

Al-Syațibī, Ibrāhim Ibn Mūsā. Al-Muwāfaqāt fì Ușūl al-Sharī'ah . Bayrūt: Mu'assasat al-Risālah, 1997.

Al-Suyūṭī, 'Abd al-Raḥmān Ibn Abī Bakr. Al-Asybāh wa alNaẓāir fì Madhhab al-Shāfì̃. Bayrūt: Dār al-Kutub alIlmiyyah, 2001.

Al-Ṭabarī, Muhammad Ibn al-Jarīr. Jāmi ‘ al-Bayān fì Ta 'wìl alQur'ān.Bayrūt: Mu'assasat al-Risālah, 2000.

Al-Ṭarīq1̄, 'Abd Allāh Muḥammad. Aḥkām al-Dhabā'ih wa alLuhūm al-Mustawradah fì al-Syarī'ah al-Islāmiyyah. Bayrūt: Mu'assasah al-Risālah, 1983.

The Religious Council Negara Brunei Darussalam (TRCNBD). Halal Food: Piawai Brunei Darussalam PBD 24: 2007. Ed ke-1. Majlis Agama Islam: Brunei Darussalam, 2007.

Wan Jasimah Wan Mohammed Radzi. "Makanan Ubah Suaian Genetik: Perspektif Kesihatan dan Keselamatan Makanan" Kertas Kerja Seminar Muzakarah Pakar Makanan - Satu Perspektif Islam. Kuala Lumpur: Institut Kefahaman Islam 
Malaysia (IKIM), 2002.

Wikipedia. Genetically Modified Food. Diakses pada 17 Oktober 2014. http://en.wikipedia.org/wiki/ Genetically_modified_ food.

World Health Organization (WHO). Modern Food Biotechnology, Human Health and Development: An Evidence-Based Study. Switzerland: WHO Library, 2005.

Al-Zuhaylī, Wahbah Ibn Mușțafā al-Fiqh al-Islāmī wa Adillatuh. Dimashq: Dār al-Fikr, 1997.

Al-Zuhaylī, Wahbah Ibn Mușțafā. Tafsīr al-Munīr. Dimashq: Dār al-Fikr, 1998.

Al-Zuhaylī, Wahbah. Ușūl al-Fiqh al-Islāmī. Dimashq: Dār alFikr, 1986. 